Tale ved åbningen af Det kongelige Biblioteks udstilling 16. juni 1992

\title{
Sjældenheder fra samlingerne
}

af professor, dr.phil. C.J. Ballhausen

Lidtoverraskende har Det kongelige Bibliotek bedt mig, en naturvidenskabsmand, sige et par ord her ved åbningen af Bibliotekets sommerudstilling. Dette kan med lidt velvilje ses i lyset af, at naturvidenskab i ældre tider var lig med naturfilosofi, dvs. en del af humaniora: H.C. Ørsted taler således om sine "naturphilosophiske arbejder". Uden at være uddannet som luftskipper skrev H.C. Ørsted et kuriøst læredigt om balloner. Denne udstilling vil jeg da ligne ved en ballon, der sendes op af Det kongelige Bibliotek for at påkalde omverdenens opmærksomhed, og alt, hvad jeg kan prøve på, er at kaste lidt ballast ud.

Hele vor nuværende kultur er bygget på bøger, de være sig humanistiske som naturvidenskabelige, og dog findes der næppe noget, der er vanskeligere at udstille - selv for et interesseret publikum - end netop bøger. Malerier, skulpturer, frimærker skal kun betragtes for at kunne tilegnes, men en bog er primært beregnet til at læses. Bogen som skueobjekt, som kunsthåndværk, er lidt selvmodsigende. Smukke og sjældne bogbind kan naturligvis beundres som kunstværker på afstand - men bedst er det dog selv at have bogen $\mathrm{i}$ hånden, mærke bindets tilpasning til bogblokken, blade i den, vurdere trykket og de eventuelle illustrationer. Og så taler jeg slet ikkeom tilegnelsen af indholdet, som for den gode bogs vedkommende er en tidrøvende proces.

En udstilling som den nærværende må derfor lægge vægt på det spektakulære, „, Sjældenheder fra samlingen“. Hvad er da en sjælden bog? Ja, det er i vore dage og måske lidt firkantet udtrykt en bog, der ikke mere findes i forlagskatalogerne. De udvalgte bøger, vi ser her, er imidlertid tillige også „rare" bøger, dvs. sjældne på grund af deres individuelle attråværdigheder - og de associationer, de kan fremkalde.

En udstilling som denne minder os også om, at der var bøger og 
åndsliv, før bogtrykkerkunsten blev opfundet. De illuminerede tidebøger og de prægtige håndskrevne koraner, der i deres udformning og skrift er store kunstværker, viser os klart middelalderens forfinede kultur som koblet til en dyb religiøsistet.

Det er blevet sagt, at „Dagens ligegyldigheder kan blive morgendagens skatte". Et smukt eksempel har vi her i den lille ABC-bog fra 1649. Det er den ældste danske ABC. Den er kun ved et tilfælde bevaret i ét eksemplar. Som bogtryk er den ligegyldig. Dog, læser vi den med nutidens øjne såre upædagogiske tekst og ser på det dårlige træsnit af hanen, årvågenhedens gamle symbol, går tankerne 350 år tilbage i tiden til den elev, der møjsommeligt sled med at lære læsningens vanskelige kunst. Måske går tankerne også til Æslet i Peter Plys, når det siger til Grislingen: „" $\mathrm{A}$ " betyder lærdom. „A“ " betyder viden - alle de ting, som du og Plys ikke har. Det er , hvad "A " betyder."

ABC'ens absolutte modsætning er Arentsches Kriegsbuch. Trykt af en af vore ypperste bogtrykkere i kun ét eksemplar for højsalig kong Frederik II, flittigt studeret af sønnen, den senere Christian IV - uden at dette dog tilsyneladende hjalp ham meget i hans krige - har dette værk altid været højt skattet og beundret. At føre krig var den høje fyrstes tidkort, og krigsførelsens intrikate kunst skulle ikke gerne spredes til rivaler. I bogen findes der da også trykt følgende vers:

„Dies Buch lernet und zeiget an
Welch nich ein jeder weis und kan,
Auch nicht ein jeder wissen sol,
Wers hat und weis, der brauch es wol.“

- Lærdom er magt, og magt har aldrig af magthaverne været beregnet til at udøves af de mange. Det har vi nylig set et eksempel på!

En lille bog, der stadig kan læses med betagelse, er Jens Munks rejsebeskrivelse fra 1624. Med sine krøllede bogstaver vil den nok volde en moderne læser besværligheder, men indholdet er så gribende i al sin nøgternhed, at det lønner sig! Man kan naturligvis nøjes med at læse Thorkild Hansens fortræffelige moderne gendigtning, men det åndelige håndtryk og den fornemmelse af nærvær, man får ved at læse Jens Munks egne ord i hans egen bog (der findes en norsk faksimile-udgave), kan ingen nok så god digterisk genfortælling erstatte. Og sådanne imponderabilia er vel den dybeste grund til de gamle førsteudgavers fascination for en nutidig læser.

Ånden og spiritualiteten i bøger kan ikke udstilles. At udstille de såre beskedne førsteudgaver af Holbergs komedier eller Andersens eventyr vil næppe bringe suset fra Kalleboderne ind i Det kongelige Bibliotek. 


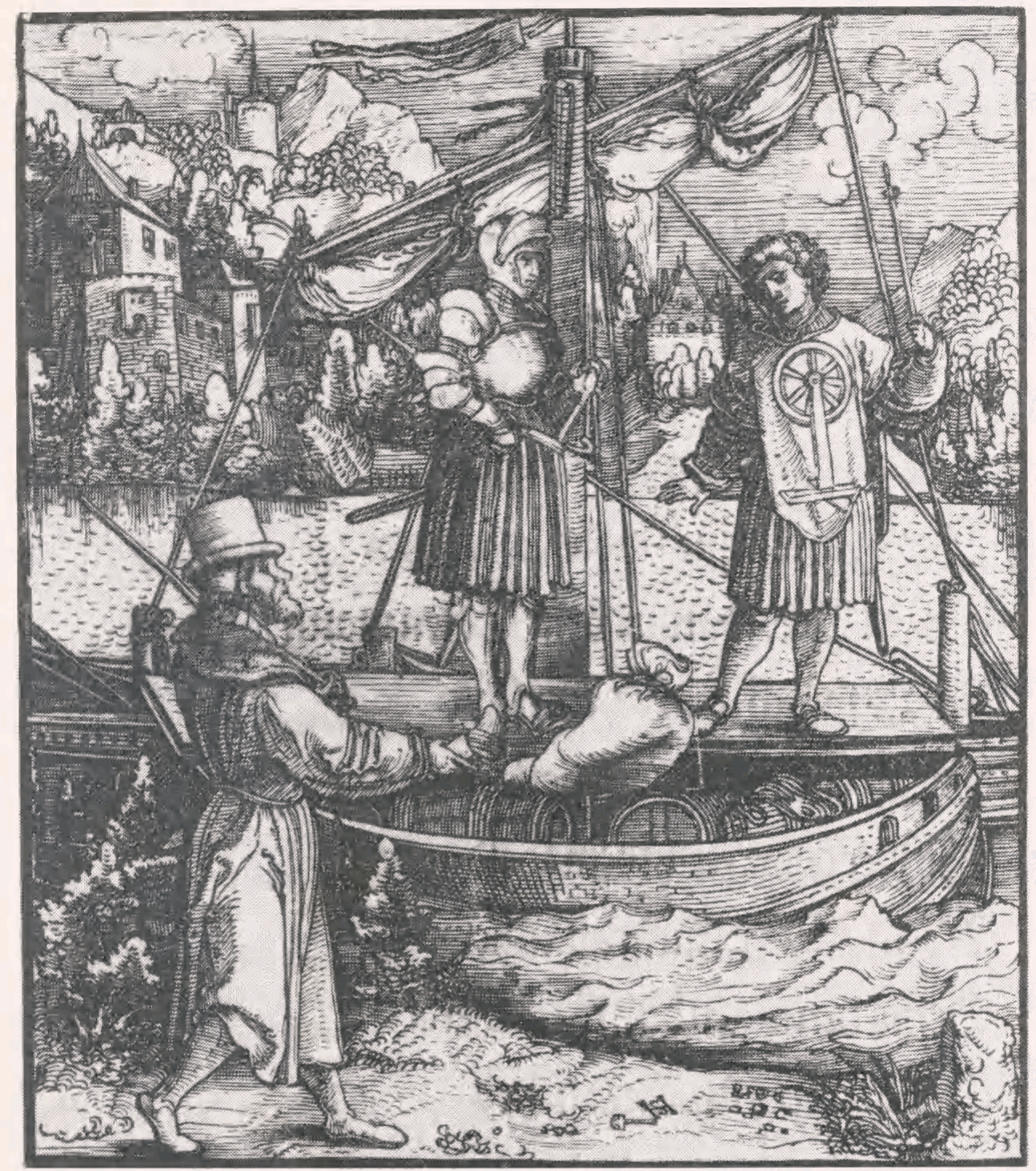

Fra sommerudstillingen:Illustration fra Die geuerlicheiten und einsteils der geschichten des loblichen streyparen und hochberumbten helds und ritters Herr Tewrdannckhs. Nürnberg 1517. Trykt på pergament. Eksemplaret har tilhørt den danske bogsamler Bolle Luxdorph.

Modsætningen, Tycho Brahes latinske Astronomiske Epistler, her brammende i et prægtigt, selvpromoverende silkebind, vil på den anden side kunne give betragteren et nokså karakteristisk begreb om den pragtelskendestore renæssance-videnskabsmand. 
Sådanne prægtige bogbind og smukke middelalder-håndskrifter er de store gamle bibliotekers prærogativer. En fryd for øjet og en kilde til misundelse for enhver besøgende bogsamler. Som sultan Soliman siger i "Aladdin":

„En ubetalelig, uhyre Skat!

Mod disse Stene ser min Krone ud, som en udklippet Tot af Guldpapir".

Bøger og manuskripter som disse samles ikke over natten. Kontinuiteten i de gamle bogsamlinger er altbetydende. Her på Det kongelige Bibliotek er bog og bind føjet til samlingen gennem 350 år. Den enkelte nok så sjældne bog kan gerne være bemærkelsesværdig, men kun i den store sammenhæng finder den sin naturlige plads.

Bøger, manuskripter, breve, kobberstik - her i Bibliotekets magasiner besidder Danmark en af verdens store samlinger. Det er ikke en død kapital, for kun ved hjælp af en stor bogsamling, gennem en udstrakt bred læsning og refleksion skabes den sande humanist.

I dagens Danmark er sansen for læsning i fare. Lokket af video og TV kommer flere og flere ud af vane med at læse. Ser vi væk fra den kommercielle underholdningslitteratur, formidler bøgerne tanker og idéer, som må tilegnes - og den tid, dette tager, beslaglægges af medierne. Den dybe respekt, der på H.C. Ørsteds tid herskede i almenheden for åndeligt arbejde, er en saga blot. Som det er sagt til Folketinget: Når bare „projektet" fra lærdomsanstalterne kan afsættes, så behøver man ikke tale om „ånd og sandhed".

En udstilling som denne er da en stilfærdig påmindelse til en materialistisk verden om, at de åndelige glæder er de sande glæder.

Og her kunne man nok ønske, at Det kongelige Bibliotek havde bedre muligheder for at formidle dette budskab. En så vidtspændende udstilling som denne er at ligne ved en kostbar diamant i en tarvelig indfatning. Hvad kan f. eks. London, Wolfenbüttel, Wien, Firenze eller Escorial iSpanien ikke byde på af udstillingsmuligheder? Når nu i 1992 en kajak fra New Guinea kan udstilles forbilledligt i Nationalmuseet, burde „Kriegsbuch" også kunne beses i et mere værdigt rum.

Vi står her i landets ældste kulturinstitution. Den fortjener at have plads, lys og luft. At samle på ånd, at pleje kontinuiteten med fortidens lærde og føre forskningen videre, kræver et engagement.

Det må ikke knægtes af dagens trivialiteter. Lad os glæde os over, hvad vi ser - men håbe på, at Bibliotekets museale og forskningsmæssige forpligtelser snart vil kunne få en ramme, der vil række fremover. 